\title{
Lipid profile and cholesterol in meat cuts of ewe lambs fed different levels of concentrate
}

\section{Perfil lipídico e colesterol em cortes cárneos de borregas alimentadas com diferentes níveis de concentrado}

\author{
Marcelo Aranda da Silva Coutinho ${ }^{1 *}$; Maria da Graça Morais ${ }^{2}$; \\ Roberta Gomes Coelho ${ }^{3}$; Fabiana Villa Alves ${ }^{4}$; Henrique Jorge Fernandes ${ }^{5}$; \\ Camila Celeste Brandão Ferreira Ítavo²; Marco Aurélio Scarton Comparin"; \\ Caroline Bertholini Ribeiro ${ }^{1}$
}

\begin{abstract}
Consumers are more interested in having healthier and better quality products. The diet offered to animals can strongly affect the composition of meat. Thus, this study aimed to evaluate the effect of different levels of concentrate on lipid profile (in natura meat) and cholesterol content (in natura and cooked meat) of ewe lambs' meat cuts. Therefore, twenty-four lambs with a mean weight of $23.1 \pm$ $2.1 \mathrm{~kg}$ were confined and fed different levels of a concentrate $(20,40,60$ and $80 \%)$ for 120 days. The diets consisted of tifton hay and concentrate based on corn and soybean meal. The muscles triceps brachii (shoulder), longissimus dorsi (loin) and semimembranosus (leg) represented the respective cuts that were analyzed. Increased levels of concentrate decreased only C18:3 (5.82 to $0.20 \mathrm{mg} / 100 \mathrm{~g})$ in meat and without affecting saturated fatty acids (SFA), unsaturated (UFA), monounsaturated (MUFA), polyunsaturated (PUFA), both desirable and total levels. Levels of concentrate had no effect on UFA/ SFA (1.01), MUFA/SFA (0.97), PUFA/SFA (0.04) ratios, or the atherogenic (AI) and thrombogenic index (TI), nor on the content cholesterol in natura and cooked meat. The meat cuts had different lipid profiles, IA, IT and cholesterol content. Concentrate levels slightly alter the lipid profile and do not alter the cholesterol content, while meat cuts are different for these components.
\end{abstract}

Key words: Fatty acids, feedlot, forage, leg, loin, shoulder

\section{Resumo}

Os consumidores estão cada vez mais interessados em consumir produtos saudáveis e de melhor qualidade. A dieta oferecida aos animais pode afetar fortemente a composição da carne. Desta forma, objetivou-se avaliar o efeito dos diferentes níveis de concentrado sobre o perfil lipídico (carne in natura) e o teor de colesterol (carne in natura e assada) dos cortes cárneos de borregas. Para isso, vinte e quatro borregas com peso médio de $23,1 \pm 2,1 \mathrm{~kg}$ foram confinadas e alimentadas com diferentes níveis de concentrado $(20,40,60$ e $80 \%)$ por 120 dias. As dietas consistiram de feno Tifton e concentrado a base de milho e farelo de soja. Os músculos tríceps brachii, (paleta), longissimus dorsi (lombo) e semimembranosus

\footnotetext{
${ }^{1}$ Mestres em Ciência Animal na Universidade Federal de Mato Grosso do Sul, Faculdade de Medicina Veterinária e Zootecnia, UFMS, Campo Grande, MS, Brasil.E-mail: marceloscoutinho@hotmail.com; mascvet@yahoo.com.br; cbr_calu@yahoo.com.br

${ }^{2}$ Prof $^{\text {as }}$., UFMS, Campo Grande, MS, Brasil. E-mail: morais.mariazinha@gmail.com; camila.itavo@ufms.br

${ }^{3}$ Pós-doutoranda, UFMS, Campo Grande, MS, Brasil. E-mail: robertacoelho@yahoo.com.br

${ }^{4}$ Pesquisadora da Embrapa Gado de Corte, Campo Grande, MS, Brasil. E-mail: fabiana.alves@embrapa.br

${ }^{5}$ Prof., UEMS, Aquidauana, MS, Brasil. E-mail: henrique.uems@hotmail.com

* Author for correspondence
} 
(pernil) representaram os respectivos cortes nas análises. O aumento dos níveis de concentrado diminuiu apenas o $\mathrm{C} 18: 3$ (5,82 para $0,20 \mathrm{mg} / 100 \mathrm{~g}$ de carne fresca) nas carnes e não alteraram os ácidos graxos saturados (AGS), insaturados (AGI), monoinsaturados (AGMI), poliinsaturados (AGPI), desejáveis e totais. Os níveis de concentrado não afetaram as relações AGI/AGS $(1,01)$, AGMI/AGS $(0,97)$, AGPI/ AGS $(0,04)$, índices aterogênico (IA) e trombogênico (IT) e nem o teor de colesterol na carne in natura e assada. Os cortes cárneos apresentaram diferenças para o perfil lipídico, IA, IT e teor colesterol. Os níveis de concentrado pouco alteram o perfil lipídico e não alteram os teores de colesterol, enquanto que os cortes cárneos são diferentes para estes componentes.

Palavras-chave: Ácidos graxos, confinamento, lombo, paleta, pernil

\section{Introduction}

The ruminant meat, important in everyday life, is a major source of saturated fat (SFA) and trans (TFA). For many years, these fats were indicated as harmful to health. In contrast, recent studies have indicated neutral or even beneficial effects of these fatty acids (FA) to health (GRUNDY, 1994; JAKOBSEN et al., 2008; SMIT; BAYLIN; CAMPOS, 2010). Adding to this, new revisions noted methodological limitations of the studies related to the consumption of red meat in human diseases (McAFEE et al., 2010; MEDEIROS, 2008). In contrast, polyunsaturated fatty acids are appointed unanimously as beneficial to health (ULBRICHT; SOUTHGATE, 1991; WOOD et al., 2003).

According to Sinclair et al. (2007), the most effective way to manipulate the fatty acid composition in sheep meat is dietary manipulation. With this aim, Demirel et al. (2006) evaluated the lipid profile in the meat of lambs fed two levels of concentrate (25 and 75\%). The authors found that diet affected lipid profile, supporting the aforementioned hypothesis of Sinclair et al. (2007). In contrast, Leão et al. (2011) found little effect of concentrate level (40 and 60\%) on lipid profile. This work, unlike previous studies, used narrow concentrate levels, which may have limited the results obtained. For this reason, it is important to evaluate ample proportions of concentrate in future studies.

Thus, the present study aimed to evaluate the effect of different concentrate levels on the lipid profile (in natura) and cholesterol content (in natura and cooked) of cuts of meat from lambs.

\section{Material and Methods}

The experimental population used in this study consisted of twenty-four newly weaned lambs, aged approximately three months, all of which were mongrel and had an average initial weight of $23.1 \pm$ $2.1 \mathrm{~kg}$. The animals were housed in individual pens with an area of $3.0 \mathrm{~m}^{2}$. Four groups of six animals were randomly assigned to one of the levels of concentrate: $20,40,60$ or $80 \%$ by dry matter basis, ad libitum for 120 days. The diets consisted of a ground forage based of Tifton 85 hay (Cynodon spp.) and concentrate based on corn and soybean meal (Table 1). 
Table 1. Chemical-bromatological composition of foods and experimental diets.

\begin{tabular}{|c|c|c|c|c|c|c|}
\hline \multirow[t]{2}{*}{ Components (g/kg dry matter) } & \multicolumn{2}{|c|}{ Foods } & \multicolumn{4}{|c|}{$\begin{array}{c}\text { Total diet } \\
\text { Concentrate levels in the diets (\%) }\end{array}$} \\
\hline & Hay & Concentrate & 20 & 40 & 60 & 80 \\
\hline Dry matter & 920 & 906 & 917 & 915 & 912 & 909 \\
\hline Organic matter & 940 & 939 & 940 & 939 & 939 & 939 \\
\hline Crude protein & 99.2 & 253 & 137 & 165 & 193 & 222 \\
\hline Ether extract & 20.5 & 31.1 & 22.6 & 24.7 & 26.9 & 29.0 \\
\hline Neutral detergent fiber & 787 & 287 & 687 & 587 & 487 & 387 \\
\hline $\mathrm{TDN}^{1}$ & - & - & 640 & 720 & 770 & 770 \\
\hline $\mathrm{TDN}^{2}$ & - & - & 680 & 730 & 770 & 770 \\
\hline
\end{tabular}

TDN: Total digestible nutrients obtained by digestibility trial in the growing (1) and termination (2).

Source: Adapted from Ribeiro (2011).

The post-weaning of lambs comprised the average body weight of $23.1 \pm 2.1 \mathrm{~kg}$ to $28.5 \pm 1.9$; $31.7 \pm 3.4 ; 34.7 \pm 1.8$ and $37.4 \pm 2.6 \mathrm{~kg}$ shrunk body weight (about 50 days of confinement) at levels of 20, 40, 60 and 80\% concentrate, respectively. From these weights, termination began which lasted until the total confinement time (growing + termination) of 120 days, with the ewe lambs reaching slaughter weights of $39.4 \pm 2.9 ; 42.3 \pm 5.1 ; 46.0 \pm 2.7$ and 50.3 $\pm 3.9 \mathrm{~kg}$ for levels $20,40,60$ and $80 \%$ concentrate, respectively.

At the end of the finishing phase, all ewe lambs were subjected to a 16 hour fasting period and then slaughtered in the Carcasses Laboratory of Embrapa Gado de Corte in Campo Grande, MS. The carcasses were cut in half and stored in a refrigerator below $5^{\circ} \mathrm{C}$ for 24 hours. The right half of the carcass was divided into meat cuts, which were placed in plastic containers and stored in a freezer at $-18^{\circ} \mathrm{C}$ for further analysis. The muscles for analyses were obtained after thawing of cuts at $10^{\circ} \mathrm{C}$ for approximately 36 hours.

In the shoulder, the lipid profile was done in the triceps brachii muscle and the cholesterol analysis in the supraspinatus muscle, while the loin and leg, for both analyses, were represented by the longissimus dorsi and semimembranosus, respectively.
Samples of $2.5 \mathrm{~cm}$ thickness of the medial portion of the supraspinatus, semimembranosus and longissimus dorsi muscle were cooked in a preheated electric oven at $300^{\circ} \mathrm{C}$. The samples remained in the oven until they reached $71^{\circ} \mathrm{C}$, and then subsamples were removed for determination of cholesterol.

For analysis of the content and FA profile, the extraction of lipids and the methylation of FA was performed using the technique of Hara and Radin (1978), with some adaptations. For this, $5 \mathrm{~g}$ of sample was added to a mixture of isopropanol/hexane (2:3) for the extraction of fatty acids. For the methylation reaction, about $40 \mathrm{mg}$ of extracted FA was weighed and placed in a small test tube. The solvents needed for the reaction (methyl acetate, sodium methoxide - 30\% in methanol) were added and the solution of anhydrous oxalic acid was finally added. Thus, the samples of esterified FA that were ready for analysis by gas chromatography were obtained.

The separation and detection of AG was achieved by gas chromatography using a Thermo chromatograph, model Trace GC Ultra, with a flame ionization detector (FID) in a fused silica capillary column $100 \mathrm{~m}$ in length, $0.25 \mathrm{~mm}$ in diameter and 0.2 $\mathrm{mm}$ in thickness (Restek RTX ${ }^{\circledR}$ - 2330, Bellefonte, PA, USA). The operating parameters of the detector were set at $270^{\circ} \mathrm{C}$ and injector temperature was 
$250^{\circ} \mathrm{C}$. The initial column temperature was $120^{\circ} \mathrm{C}$ (5 min), increasing gradually until $240^{\circ} \mathrm{C}(15 \mathrm{~min})$ at a rate of $3{ }^{\circ} \mathrm{C} / \mathrm{min}$. For the carrier gas, helium was used with a flow rate of $1.5 \mathrm{ml} / \mathrm{min}$. For injection, $1 \mu 1$ of sample was used. Data on retention times and percentages of components were obtained from Chrom Quest Version 4.2 software. The identification and quantification of fatty acids was assessed using retention time and comparison of this time with co-injection of the methyl esters of fatty acids of samples patterns.

The atherogenic (AI) and thrombogenic index (TI) were calculated according to Ulbricht and Southgate (1991), where AI $=($ C12:0 +4 x C14:0 + C16:0)/(n-6 PUFA + n-3 PUFA + MUFA); TI $=(\mathrm{C} 14: 0+\mathrm{C} 16: 0+\mathrm{C} 18: 0) /[0.5 \times \mathrm{n}-6$ PUFA + $3 \times$ n-3 PUFA $+0.5 \times$ MUFA + (n-3 PUFA / n-6 PUFA)]. The contents of desirable fatty acids (DFA) were calculated according to Rhee (1992). DFA = (n-3 PUFA + n-6 PUFA + MUFA + C18:0), where n-6 PUFA: omega-6 polyunsaturated fatty acids, n-3 PUFA: omega-3 polyunsaturated fatty acids; MUFA: monounsaturated fatty acids.

Cholesterol was extracted from the meat samples following the methodology for extracting published by Saldanha, Santana and Gaspar (2002). The spectrophotometric analysis for the determination followed the methodology of Zenebon and Pascuet (2008).

Data were analyzed in a completely randomized design with a factorial arrangement $3 \times 4$ (three meat cuts $\mathrm{x}$ four levels of concentrate). The model included the linear and quadratic effects of concentrate level. Interactions were evaluated and removed from the model when not significant. The slaughter weight of ewe lambs was used as a covariate in order to eliminate the interference of those on the composition of meat cuts. Where appropriate, the Tukey test was used to compare the means of cuts. The PROC GLM in SAS v 9.2 (SAS Institute Inc.) was used in all statistical analyses. A significance level of 5\% was adopted.

\section{Results and Discussion}

Post-weaning, the dry matter intake (g/day) and average daily gain (g/day) were $1196 \pm 28$ and $135 \pm 14 ; 1139 \pm 23$ and $168 \pm 11 ; 1177 \pm 23$ and $218 \pm 11 ; 1193 \pm 28$ and $246 \pm 13$ for levels of 20 , 40,60 and $80 \%$ concentrate, respectively. While the termination the dry matter intake (g/day) and average daily gain (g/day) were $1450 \pm 41$ and 162 $\pm 19 ; 1328 \pm 31$ and $159 \pm 15 ; 1295 \pm 31$ and 162 $\pm 15 ; 1207 \pm 41$ and $171 \pm 19$ for levels of 20, 40, 60 and $80 \%$ concentrate, respectively. Additional information about the performance is available in the work of Ribeiro (2011).

The different levels of concentrate in the diet showed meats with lipid profiles that were slightly different (Table 2). Of the eleven AG studied, only the n-3 C18:3 were significantly different between treatments. The highest levels of forage conditioned meats were reported with higher levels of n-3 C18:3. This was also observed in confined sheep by Demirel et al. (2006), Velasco et al. (2004) and Aurousseau et al. (2004) in different production systems. Unlike the current study, the previous studies used temperate grasses. However, Menezes et al. (2010) showed that tropical grasses can also provide superior results to $\mathrm{n}-3 \mathrm{C} 18: 3$ because they observed higher C18:3 in the duodenum (available for uptake and tissue deposition) of animals fed tropical grass-based diets than in animals fed concentrate-based and temperate grasses, $0.61,0.0$ and $0.0 \mathrm{~g} /$ day, respectively.

The C18:0, which has high levels in the meat of ruminants, is improperly recorded as hypercholesterolemic. Bragagnolo (2001), when the C18:0 was subtracted from the total of SFA in chicken, pork and beef, observed values of 28,28 and $31 \%$, respectively, of potentially hypercholesterolemic SFA in these meats. In this sense, the ewe lambs in this study had a mean value of $30.12 \%$ hypercholesterolemic SFA, which was very close to the above meats.

Rumenic acid (cis-9 trans-11 C18:2), the main 
isomer of CLA produced by ruminants (SCOLLAN et al, 2006), has reported anticancer properties (McAfee et al., 2010). The main sources of CLA in the human diet come from the meat and milk of ruminants. Pellegrini et al. (2007) observed an average value of $30.1 \mathrm{mg} / 100 \mathrm{~g}$ of in natura meat for this $A G$ in sheep, whereas the mean value observed here was much lower $(2.49 \mathrm{mg} / 100 \mathrm{~g}$ in natura meat). Santos-Silva, Bessa and Santos-
Silva (2002) found that treatments with higher levels of concentrate increased the CLA in meat, which ranged from 0.24 to $0.87 \mathrm{mg} / 100 \mathrm{~g}$ in natura meat. Briefly, there seems to be a tendency towards a quadratic relationship between levels of concentrate and CLA $(\mathrm{P}<0.08)$, agreeing with the divergent findings observed in the comparison of production systems (AUROUSSEAU et al., 2004; NUERNBERG et al., 2008).

Table 2. Lipid profile, fatty acid groups, relationships between groups of fatty acids, atherogenic and thrombogenic index of in natura meat of ewe lambs fed different levels of concentrate.

\begin{tabular}{|c|c|c|c|c|c|c|c|}
\hline \multirow[t]{2}{*}{ Variables } & \multicolumn{4}{|c|}{ Level of concentrate in the diet $(\%)$} & \multirow{2}{*}{$\begin{array}{l}\text { C.V. } \\
(\%)\end{array}$} & \multicolumn{2}{|c|}{$\begin{array}{l}\text { Value - P Effect of } \\
\text { concentrate level }\end{array}$} \\
\hline & 20 & 40 & 60 & 80 & & Linear & Quadratic \\
\hline \multicolumn{8}{|c|}{ Fatty acids, mg/100 g meat } \\
\hline C14:0 & 30.64 & 47.73 & 37.46 & 38.11 & 45.57 & 0.063 & 0.075 \\
\hline $\mathrm{C} 16: 0$ & 574.47 & 646.81 & 492.86 & 511.32 & 58.17 & 0.922 & 0.789 \\
\hline $\mathrm{C} 16: 1$ & 11.72 & 15.83 & 16.69 & 19.79 & 47.56 & 0.453 & 0.821 \\
\hline $\mathrm{C} 17: 0$ & 184.41 & 195.23 & 139.67 & 163.86 & 47.90 & 0.511 & 0.651 \\
\hline $\mathrm{C} 17: 1$ & 3.95 & 4.59 & 3.80 & 5.59 & 47.08 & 0.387 & 0.223 \\
\hline C18:0 & 639.98 & 738.77 & 455.66 & 385.38 & 53.47 & 0.634 & 0.290 \\
\hline C18:1 & 937.57 & 1332.70 & 1026.72 & 1272.19 & 47.77 & 0.527 & 0.675 \\
\hline $\mathrm{C} 18: 2$ & 20.36 & 26.86 & 26.32 & 29.72 & 32.25 & 0.236 & 0.501 \\
\hline CLA & 1.88 & 2.12 & 2.10 & 3.84 & 71.60 & 0.233 & 0.080 \\
\hline n-3 C18:3 & 5.82 & 2.63 & 1.02 & 0.20 & 40.60 & $<0.001$ & $<0.001$ \\
\hline$n-6 C 20: 4$ & 9.09 & 11.97 & 13.60 & 14.80 & 36.96 & 0.175 & 0.463 \\
\hline \multicolumn{8}{|c|}{ Groups of fatty acids, $\mathrm{mg} / 100 \mathrm{~g}$} \\
\hline SFA & 1433.66 & 1630.72 & 1126.68 & 1100.42 & 51.93 & 0.833 & 0.571 \\
\hline IFA & 990.40 & 1396.70 & 1090.27 & 1346.15 & 46.54 & 0.526 & 0.683 \\
\hline MUFA & 953.10 & 1353.12 & 1047.22 & 1297.57 & 47.61 & 0.528 & 0.680 \\
\hline PUFA & 37.16 & 43.58 & 43.04 & 48.58 & 32.18 & 0.644 & 0.944 \\
\hline DFA & 1630.38 & 2135.47 & 1545.93 & 1731.53 & 47.17 & 0.550 & 0.514 \\
\hline Total FA & 2424.07 & 3027.42 & 2216.95 & 2446.58 & 48.06 & 0.680 & 0.611 \\
\hline \multicolumn{8}{|c|}{ Groups of fatty acids, $\%$ of total fatty acid } \\
\hline SFA & 59.34 & 52.35 & 49.32 & 42.52 & 11.83 & 0.158 & 0.990 \\
\hline IFA & 40.78 & 47.62 & 50.67 & 57.34 & 12.16 & 0.170 & 0.982 \\
\hline MUFA & 38.98 & 46.46 & 48.32 & 55.00 & 12.47 & 0.167 & 0.996 \\
\hline PUFA & 1.64 & 1.69 & 2.23 & 2.52 & 39.49 & 0.914 & 0.606 \\
\hline DFA & 67.48 & 71.52 & 71.50 & 72.53 & 6.47 & 0.080 & 0.207 \\
\hline \multicolumn{8}{|c|}{ Relations among fatty acids, and thrombogenic and atherogenic index } \\
\hline IFA/SFA & 0.68 & 0.93 & 1.08 & 1.35 & 23.40 & 0.248 & 0.761 \\
\hline MUFA/SFA & 0.65 & 0.89 & 1.03 & 1.29 & 23.40 & 0.240 & 0.785 \\
\hline PUFA/SFA & 0.03 & 0.03 & 0.05 & 0.06 & 42.44 & 0.913 & 0.433 \\
\hline AI & 0.72 & 0.58 & 0.56 & 0.46 & 31.43 & 0.286 & 0.724 \\
\hline TI & 2.50 & 1.96 & 1.78 & 1.24 & 31.82 & 0.313 & 0.946 \\
\hline
\end{tabular}

Source: Elaboration of the authors. 
In this work, the different forage:concentrate ratios $(F: C)$ slightly interfered with the FA content of flesh meat. This contrasts with the results published by Sinclair et al. (2007), which showed that dietary manipulation is an effective means of altering the lipid profile in ruminants. These results also contrast with the findings of Demirel et al. (2006), who observed a significant effect of diet on lipid profile.

As a result, there was no effect $(\mathrm{P}>0.05)$ of concentrate level on the absolute ( $\mathrm{mg} / 100 \mathrm{~g}$ of meat) and relative (\%) values of the SFA, IFA, MUFA, PUFA and DFA (Table 2). Similarly, Leão et al. (2011) evaluated two concentrate levels (40 and $60 \%$ ) and found no difference between treatments for SFA (51.27 and 51.40\%), IFA (48.73 and 48.60\%), MUFA (40, 10 and 39.89\%) and PUFA (8.63 and $8.72 \%$ ) and little effect on FA. When compared to the reviewed studies, the meat of ewe lambs evaluated here showed levels of DFA and MUFA that were high and low PUFA levels. High concentrations of $\mathrm{C} 18: 0$ and $\mathrm{C} 18: 1$ and reduced C18:3 were preponderant for these results.

The different $\mathrm{V}: \mathrm{C}$ proportions did not affect ( $>0.05$, Table 2 ) the relationship between FA (IFA/ SFA, MUFA/SFA, PUFA/SFA), a consequence of the lack of differences from the other results. In the same direction, following the atherogenic (AI) and thrombogenic index (TI), those evaluated in the meat of ewe lambs were not affected by different levels of concentrate ( $P>0.05$, Table 2). Mean values for $\mathrm{AI}$ and TI were 0.58 and 1.87 , respectively.

Changing the fat profile of beef with different concentrate levels could be due to differences in the flow of the AG that reach the gut for tissue deposition. However, this hypothesis is rejected if the biohydrogenation rate in rumen is higher than the passage rate of the different diets (PETROVA; BANSKALIEVA; DIMOV, 1994). In general, the biohydrogenation rates are high, as reported by Ribeiro et al. (2007), who published values from 23.5 to $27.4 \%$ /h for $\mathrm{C} 18: 2$ and 30.3 to $43.8 \% / \mathrm{h}$ for
C18:3, in accordance with the buffer used, weak or strong, respectively.

A second hypothesis is about the energy concentration of the diets. Higher levels of concentrates normally provide greater energy concentration in the diet. Thus, higher performance is expected, and therefore, the physiological maturity and deposition of adipose tissue is achieved earlier. This process has a strong influence on lipid profile, as discussed in the review of Scollan et al. (2006) and demonstrated by Warren et al. (2008). These last authors observed that while intramuscular fat increased with age, or in earlier breeds or higher energy diets, an increase in neutral lipids occurred (rich in SFA and to a lesser extent in MUFA), which reduced the percentage phospholipids that are rich in PUFAs in cattle.

Based on these assumptions, the similarity in the lipid profile of meat from animals fed with different levels of concentrate may result from severe ruminal biohydrogenation and the lack of differences in the deposition of intramuscular fat (TFA) between treatments. The main candidate factors for the similarity of these variables are the small difference in energy concentrations of the diets; the low efficiency of nutrient utilization by ewe lambs; slaughter before they reach physiological maturity; and low genetic potential for intramuscular fat deposition.

This similarity in the lipid profile related to deposition of intramuscular fat is reinforced by the results obtained when comparing meat cuts, where the fatter cut (loin) showed the highest levels of SFA and lower PUFA, while the less fatty cuts showed the lowest levels of SFA and higher PUFA (Table 3).

In assessing the lipid profile of meat cuts, the content of $\mathrm{C} 18: 2$ did not differ $(\mathrm{P}>0.05)$ between loin, shoulder and leg (Table 3). The other FA differed between at least two cuts. The SFA C14:0 and $\mathrm{C} 16: 0$ were higher in loin, while the $\mathrm{C} 17: 0$ and C18:0 did not differ between the loin and shoulder, 
but showed higher concentrations in these cuts in relation to leg. Referring to monounsaturated FA (MUFA), it was observed that the loin showed higher levels for $\mathrm{C} 16: 1$. For $\mathrm{C} 17: 1$, the shoulder had higher levels than leg and similar levels to loin. The shoulder did not differ from other cuts for $\mathrm{C} 18: 1$, while the loin was greater than the leg for this FA.
The CLA, C18:3 and C20:4 may help to prevent cardiovascular disease and hypertension in humans because they are IFA (McAfee et al., 2010). The shoulder and leg did not differ and had the highest concentrations of CLA and C20:4 among all of the cuts. For C18:3, the shoulder was higher than the loin and leg. The superiority of the loin for most FA is a result of the higher concentration of lipids (Total FA, Table 3).

Table 3. Lipid profile, fatty acid groups, relationships between groups of fatty acids, atherogenic index and thrombogenic index of in natura meat cuts of ewe lambs.

\begin{tabular}{|c|c|c|c|c|}
\hline \multirow{2}{*}{ Variables } & \multicolumn{3}{|c|}{ Meat cuts ${ }^{1}$} & \multirow{2}{*}{$\begin{array}{l}\text { C.V. } \\
(\%)\end{array}$} \\
\hline & Loin & Shoulder & Leg & \\
\hline \multicolumn{5}{|c|}{ Fatty acids, mg/100 g meat } \\
\hline C14:0 & $49.65^{\mathrm{a}}$ & $37.30^{\mathrm{b}}$ & $27.63^{\mathrm{b}}$ & 45.57 \\
\hline $\mathrm{C} 16: 0$ & $932.85^{\mathrm{a}}$ & $275.13^{\mathrm{b}}$ & $448.39^{b}$ & 58.17 \\
\hline $\mathrm{C} 16: 1$ & $21.34^{\mathrm{a}}$ & $15.63^{\mathrm{b}}$ & $11.28^{\mathrm{b}}$ & 47.56 \\
\hline $\mathrm{C} 17: 0$ & $216.85^{\mathrm{a}}$ & $170.63^{\mathrm{ab}}$ & $121.07^{\mathrm{b}}$ & 47.90 \\
\hline $\mathrm{C} 17: 1$ & $4.49^{\mathrm{ab}}$ & $5.53^{\mathrm{a}}$ & $3.43^{\mathrm{b}}$ & 47.08 \\
\hline $\mathrm{C} 18: 0$ & $732.93^{\mathrm{a}}$ & $551.95^{\mathrm{ab}}$ & $351.91^{\mathrm{b}}$ & 53.47 \\
\hline $\mathrm{C} 18: 1$ & $1488.59^{\mathrm{a}}$ & $1008.21^{\mathrm{ab}}$ & $914.01^{\mathrm{b}}$ & 47.77 \\
\hline $\mathrm{C} 18: 2$ & 22.91 & 28.66 & 25.98 & 32.25 \\
\hline CLA & $2.06^{\mathrm{b}}$ & $3.36^{\mathrm{a}}$ & $2.12^{\mathrm{ab}}$ & 71.60 \\
\hline n-3 C18:3 & $1.77^{\mathrm{b}}$ & $3.13^{\mathrm{a}}$ & $2.17^{\mathrm{b}}$ & 40.60 \\
\hline $\mathrm{n}-6 \mathrm{C} 20: 4$ & $8.13^{\mathrm{b}}$ & $14.52^{\mathrm{a}}$ & $14.65^{\mathrm{a}}$ & 36.96 \\
\hline \multicolumn{5}{|c|}{ Groups of fatty acids, $\mathrm{mg} / \mathbf{1 0 0} \mathrm{g}$} \\
\hline SFA & $1934.96^{\mathrm{a}}$ & $1037.80^{\mathrm{b}}$ & $950.31^{\mathrm{b}}$ & 51.93 \\
\hline IFA & $1549.29^{\mathrm{a}}$ & $1079.05^{b}$ & $973.63^{\mathrm{b}}$ & 46.54 \\
\hline MUFA & $1514.74^{\mathrm{a}}$ & $1029.37^{b}$ & $928.71^{\mathrm{b}}$ & 47.61 \\
\hline PUFA & $34.88^{\mathrm{b}}$ & $49.68^{\mathrm{a}}$ & $44.92^{\mathrm{a}}$ & 32.18 \\
\hline DFA & $2282.22^{\mathrm{a}}$ & $1631.00^{\mathrm{b}}$ & $1325.54^{\mathrm{b}}$ & 47.17 \\
\hline Total FA & $3484.25^{\mathrm{a}}$ & $2116.85^{\mathrm{b}}$ & $1923.94^{\mathrm{b}}$ & 48.06 \\
\hline \multicolumn{5}{|c|}{ Groups of fatty acids, $\%$ of total fatty acids } \\
\hline SFA $(\%)$ & $55.10^{\mathrm{a}}$ & $48.60^{\mathrm{b}}$ & $48.38^{b}$ & 11.83 \\
\hline IFA (\%) & $44.91^{\mathrm{b}}$ & $51.37^{\mathrm{a}}$ & $51.59^{\mathrm{a}}$ & 12.16 \\
\hline MUFA (\%) & $43.81^{\mathrm{b}}$ & $48.91^{\mathrm{a}}$ & $48.91^{\mathrm{a}}$ & 12.47 \\
\hline PUFA (\%) & $0.99^{\mathrm{b}}$ & $2.43^{\mathrm{a}}$ & $2.69^{\mathrm{a}}$ & 39.49 \\
\hline DFA $(\%)$ & $65.29^{c}$ & $77.34^{\mathrm{a}}$ & $69.68^{\mathrm{b}}$ & 6.47 \\
\hline \multicolumn{5}{|c|}{ Relations among fatty acids, and thrombogenic and atherogenic index } \\
\hline IFA/SFA & $0.84^{\mathrm{b}}$ & $1.11^{\mathrm{a}}$ & $1.10^{\mathrm{a}}$ & 23.40 \\
\hline PUFA/SFA & $0.02^{\mathrm{b}}$ & $0.05^{\mathrm{a}}$ & $0.06^{\mathrm{a}}$ & 23.40 \\
\hline MUFA/SFA & $0.82^{\mathrm{b}}$ & $1.06^{\mathrm{a}}$ & $1.04^{\mathrm{a}}$ & 42.44 \\
\hline AI & $0.76^{\mathrm{a}}$ & $0.41^{\mathrm{c}}$ & $0.56^{\mathrm{b}}$ & 31.43 \\
\hline TI & $2.26^{\mathrm{a}}$ & $1.66^{\mathrm{b}}$ & $1.64^{\mathrm{b}}$ & 31.82 \\
\hline
\end{tabular}

${ }^{1}$ Means followed by different letters on the lines differ $(\mathrm{P}<0.05)$ by Tukey test at $5 \%$ probability $(\mathrm{P}<0.05)$.

Source: Elaboration of the authors. 
The loin showed the highest concentrations of saturated fatty acids $(\mathrm{p}<0.05)$, with no significant difference $(p>0.05)$ between the shoulder and leg for these FA (Table 3). Oriani et al. (2005) found no difference $(\mathrm{p}>0.05)$ for SFA among the longissimus dorsi (52.52\%), semimembranosus (50.82\%) and quadriceps femoris (53.81\%) of lambs, which is in contrast with the current study.

The loin also had the highest content of MUFA in absolute values, but lower in relative values. This cut also presented the lowest PUFA and SFA in both units. From these results, the loin can be characterized precipitously with a worse lipid profile. However, C18:0 is the main SFA and is not considered undesirable. Considering this, the DFA (mg/100 g of meat) levels were higher in the loins among the meat cuts studied here (Table 3), with the shoulder and leg similar to this variable. In relative values, the findings for this lipid group were different. In this unit, the shoulder had the highest value followed by leg and loin. These differences between the units are due to the higher content of total FA in the loins, which increase all other FA groups (mg/100 g), but the SFA and MUFA were mainly present at higher concentrations. Thus, depending on the unit, the loin can be considered a more or less desirable cut.

In this sense, the relationship among the FA can be good measures to define the cut with better dietary recommendation. The shoulder and the leg did not differ for IFA/SFA, PUFA/SFA and MUFA/SFA ( $P>0.05$, Table 3$)$, and had levels that were higher than those of the loin. High values of PUFA/SFA are important to prevent the risk of cardiovascular disease. Wood et al. (2003) reported that the Department of Health of the United Kingdom recommends that the PUFA/ SFA should be at least 0.4. According to Scollan et al. (2006), feeding management can only slightly improve the PUFA/SFA in ruminants. This variable ranges from $0.06-0.15$ due to the high degree of IFA biohydrogenation in the rumen. In the current study, this ratio ranged from 0.04 to
0.06 in the different cuts, which was slightly below the minimum normally found and far below the recommended levels.

The AI was higher in the loins, followed by in the leg and shoulder (Table 3). The TI tended to follow the same conduct of AI, with higher values in the loin. However, the shoulder TI was similar to leg TI. The results seen here for AI can be considered low, because they ranged from 0.41 to 0.76 . These values are close to the lower limit found in previous studies, which ranged from 0.74 to 1.50 (ORIANI et al., 2005; SALVATORI et al., 2004). These low AI values are caused by the non-detection of C12:0, low levels of C14:0 and high levels of C18:1 in the meat. The first two FA have atherogenic activity. However, the C14:0 is the most damaging, while the C18:1, as well as the fatty acids $n-6$ and $n-3$, are recognized by the potential anti-atherogenic activity.

In contrast to $\mathrm{AI}$, the values recorded for $\mathrm{TI}$ were high; this index ranged from 1.64 to 2.26 in meat of ewe lambs. The main factors contributing to this result were the high content of C18:0, which is considered a thrombogenic fatty acid in the calculation of TI, combined with low levels of omega-3 polyunsaturated fatty acids (recognized by anti-thrombogenic activity).

Similarly to the results observed here in ewe lambs, Oriani et al. (2005) observed higher values of TI in the loins of lambs than in the leg (1.69 and 1.57 , respectively). Compared to the literature data, the cuts of ewe lambs showed low atherogenic and high thrombogenic capacity. Among the cuts, the shoulder obtained the most appropriate indices (minors $\mathrm{AI}$ and $\mathrm{TI}$ ).

Cholesterol levels of both cooked and in natura meat did not show linear nor quadratic effects of different levels of concentrate in the diet (Table 4). On average, the in natura meat showed values of $74.53 \mathrm{mg} / 100 \mathrm{~g}$, while the roast beef recorded an average value of $103.29 \mathrm{mg} / 100 \mathrm{~g}$, being statistically higher $(\mathrm{P}<0.001)$ than in the in natura 
meat (data not shown in table). In fact, according to Bragagnolo and Baggio (2006), the water lost during heat treatment exerts an increase in the concentration of cholesterol in the meat.

Table 4. Cholesterol content of in natura and cooked ewe lambs fed different levels of concentrate in the diets.

\begin{tabular}{|c|c|c|c|c|c|c|c|}
\hline \multirow{2}{*}{$\begin{array}{c}\text { Cholesterol } \\
\text { (mg/100g meat) }\end{array}$} & \multicolumn{4}{|c|}{ Level of concentrate in the diet (\%) } & \multirow{2}{*}{$\begin{array}{l}\text { C.V. } \\
(\%)\end{array}$} & \multicolumn{2}{|c|}{ Value - P Effect } \\
\hline & 20 & 40 & 60 & 80 & & Linear & Quadratic \\
\hline In natura & 78.31 & 74.16 & 74.41 & 71.22 & 16.41 & 0.658 & 0.869 \\
\hline Cooked & 104.05 & 99.43 & 102.05 & 107.63 & 19.36 & 0.351 & 0.284 \\
\hline
\end{tabular}

Source: Elaboration of the authors.

In the literature, few studies have assessed the levels of cholesterol in meat treated thermally. Bragagnolo and Baggio (2006), comparing the in natura and cooked meats, observed that only beef meatballs (among the products studied) exhibited higher cholesterol content after cooking $(25.7 \pm 0.4$ against $27.8 \pm 06 \mathrm{mg} / 100 \mathrm{~g}$ ), in contrast to other products (no differences).

Similar to the current study, Leão et al. (2011) studied the possible effect of two levels of concentrate (40 and $60 \%$ ) on the cholesterol content in meat from lambs and found no difference, with an average value of $51.10 \mathrm{mg} / 100 \mathrm{~g}$. In contrast, Arruda et al. (2012) found negative linear behavior in the levels of cholesterol in the loins (in natura), while increasing the energy density of diets. The values obtained by those authors ranged from 21.74 to $54.06 \mathrm{mg} / 100 \mathrm{~g}$ (much lower than those reported here). Based on these studies, it appears that the effects of concentrate levels on cholesterol levels in sheep meat are still not well understood, and sometimes independent of feeding, as in this case.

In natura cholesterol values were shown to be below those of cooked cuts $(\mathrm{P}<0.05$, Table 5$)$. The meat cuts showed significant differences $(\mathrm{P}<0.05)$ for cholesterol in both in natura and cooked meat (Table 5). For cholesterol in fresh beef, the loin and leg did not differ, and the last did not differ from the shoulder, while in the cooked meat, the loin had the lowest cholesterol concentration among the cuts, with the shoulder and leg not differing $(\mathrm{P}>0.05)$. No explanation was found for the behavior of the cholesterol content in the loin (the highest among the in natura meats and the lowest among the cooked), since the cuts showed the same cooking methodology.

Table 5. Cholesterol content of in natura and cooked the loin, shoulder and leg of ewe lambs.

\begin{tabular}{|c|c|c|c|c|}
\hline \multirow{2}{*}{$\begin{array}{c}\text { Cholesterol } \\
\text { (mg/100 g meat) }\end{array}$} & \multicolumn{3}{|c|}{ Cuts $^{1}$} & \multirow{2}{*}{$\begin{array}{l}\text { C.V. } \\
(\%)\end{array}$} \\
\hline & Loin & Shoulder & Leg & \\
\hline In natura & $77.83^{\mathrm{aB}}$ & $69.12^{\mathrm{bB}}$ & $76.64^{\mathrm{abB}}$ & 16.41 \\
\hline Cooked & $91.69^{\mathrm{bA}}$ & $106.54^{\mathrm{aA}}$ & $111.65^{\mathrm{aA}}$ & 19.36 \\
\hline C.V. $(\%)$ & 22.54 & 17.15 & 16.36 & \\
\hline
\end{tabular}

${ }^{1}$ Means followed by different uppercase letters in the column and lowercase letters in the line differ by Tukey test at $5 \%$ probability $(\mathrm{P}<0.05)$.

Source: Elaboration of the authors. 
In contrast to the findings obtained in the current study, Solomon et al. (1991) observed similarities in the levels of cholesterol among loin, shoulder and leg when derived from animals on the same diet. In general, these authors showed concentrations from 70.4 to $78.1 \mathrm{mg} / 100 \mathrm{~g}$, which were similar to those observed here.

The cuts were different for cholesterol levels in both in natura and cooked meat. The values obtained in fresh meat are close to those reported in the literature. However, for processed (cooked) sheep meat, no reference values were found; therefore, more descriptions of meat quality ready for consumption are required.

\section{Conclusions}

The variations in the level of concentrate in the diets altered the lipid profile only slightly and did not influence the cholesterol content of the meat of ewe lambs, allowing us to recommend the use of diets with large variations in forage:concentrate ratios on the production of sheep meat.

The shoulder has achieved the best recommendations for lipid profile, unlike the loin. However, the cooked loin cut was the best for low cholesterol consumption. The meat cuts this study can be considered good for their lipid composition, with regular amounts of SFA, high IFA and low cholesterol levels.

The cooked meat cuts have higher cholesterol levels than fresh meat.

\section{References}

ARRUDA, P. C. L.; PEREIRA, E. S.; PIMENTEL, P. G.; BOMFIM, M. A. D.; MIZUBUTI, I. Y.; RIBEIRO, E. L. A.; FONTENELE, L. M.; REGADAS FILHO, J. G. L. Perfil de ácidos graxos no Longissimus dorsi de cordeiros Santa Inês alimentados com diferentes níveis energéticos. Semina: Ciências Agrárias, Londrina, v. 33, n. 3, p. 1229-1240, 2012.
AUROUSSEAU, B.; BAUCHART, D.; CALICHON, E.; MICOL, D.; PRIOLO, A. Effect of grass or concentrate feeding systems and rate of growth on triglyceride and phospholipid and their fatty acids in the M. longissimus thoracis of lambs. Meat Science, Amsterdam, v. 66, n. 3, p. 531-541, 2004.

BAGGIO, S. R.; BRAGAGNOLO, N. The effect of heat treatment on the cholesterol oxides, cholesterol, total lipid and fatty acid contents of processed meat products. Food Chemistry, London, v. 95, n. 4, p. 611-619, 2006.

BRAGAGNOLO, N. Aspectos comparativos entre carnes segundo a composição de ácidos graxos e teor de colesterol. In: CONFERÊNCIA INTERNACIONAL VIRTUAL SOBRE QUALIDADE DE CARNE SUÍNA, 2001. Concórdia. Anais... Concórdia: Embrapa Suínos e Aves, 2001. Disponível em: <http://www.cnpsa.embrapa. $\mathrm{br} / \mathrm{sgc} / \mathrm{sgc}$ _publicacoes/anais01cv2_bragagnolo_ pt.pdf $>$. Acesso em: 03 ago. 2013.

DEMIREL, G.; OZPINAR, H.; NAZLI, B.; KESER, O. Fatty acids of lamb meat from two breeds fed different forage: concentrate ratio. Meat Science, Amsterdam, v. 72, n. 2, p. 229-235, 2006.

GRUNDY, S. M. Influence of stearic acid on cholesterol metabolism relative to other long-chain fatty acids. The American Journal of Clinical Nutrition, Houston, v. 60, n. 6, p. 986-990, 1994.

HARA, A.; RADIN, N. S. Lipid extraction of tissues with low-toxicity solvent. Analytical Biochemistry, New York, v. 90, n. 1, p. 420-426, 1978.

JAKOBSEN, M. U.; OVERVAD, K.; DYERBERG, J.; HEITMANN, B. L. Intake of ruminant trans fatty acids and risk of coronary heart disease. International Journal of Epidemiology, Oxford, v. 37, n. 1, p. 173-182, 2008.

LEÃO, A. G.; SILVA SOBRINHO, A. G.; MORENO, G. M. B.; SOUZA, H. B. A. S.; PEREZ, H. L.; LOUREIRO, C. M. B. Características nutricionais da carne de cordeiros terminados com dietas contendo cana-deaçúcar ou silagem de milho e dois níveis de concentrado. Revista Brasileira de Zootecnia, Viçosa, v. 40, n. 5, p. 1072-1079, 2011.

MCAFEE, A.; MCSORLEY, E.; CUSKELlY, G.; MOSS, B. W.; WALLACE, J. M. W.; BONHAM, M. P.; FEARON, A. M. Red meat consumption: An overview of the risks and benefits. Meat Science, Amsterdam, v. 84, n. 1, p. 1-13, 2010.

MEDEIROS, S. R. Valor nutricional da carne bovina e suas implicações para a saúde humana. Campo Grande, MS: Embrapa Gado de Corte, 2008. 30 p. 
MENEZES, L. F. G.; KOZLOSKI, G. V.; RESTLE, J.; BRONDONI, I. L.; PAZDIORA, R. D.; CATTELAM, J. Profile of ingested fatty acids and in the duodenal digest of steers fed different diets. Revista Brasileira de Zootecnia, Viçosa, v. 39, n. 11, p. 2502-2511, 2010.

NUERNBERG, K.; FISCHER, A.; NUERNBERG, G.; ENDER, K.; DANNENBERGER, D. Meat quality and fatty acid composition of lipids in muscle and fatty tissue of skudde lambs fed grass versus concentrate. Small Ruminant Research, Amsterdam, v. 74, n. 1, p. 279-283, 2008.

ORIANI, G.; MAIORANO, G.; FILETTI, F. CESARE, C. D.; MANCHISI, A.; SALVATORI, G. Effect of age on fatty acid composition of Italian Merino suckling lambs. Meat Science, Amsterdam, v. 71, n. 3, p. 557-562, 2005.

PELEGRINI, L. F.V.; PIRES, C. C.; KOZLOSKI, G. V.; TERRA, N. N.; BAGGIO, S. R.; BASTIANELLO, P. C.; CAMPAGNOL, P. C.B.; GALVANI, D. B.; CHEQUIM, R. M. Perfil de ácidos graxos da carne de ovelhas de descarte de dois grupos genéticos submetidas a dois sistemas de manejo. Ciência Rural, Santa Maria, v. 37, n. 6, p. 1786-1790, 2007.

PETROVA, Y.; BANSKALIEVA, V.; DIMOV, V. Effect of feed on distribution of fatty acids at Sn-2-position in triacylglycerols of different adipose tissues in lambs. Small Ruminant Research, Amsterdam, v. 13, n. 3, p. 263-267, 1994.

RHEE, K. S. Fatty acids in meats and meat products. In: CHOW, C. K. (Ed.). Fatty acids in foods and their health implications. Marcel Dekker, New York, 1992. p. 65-93.

RIBEIRO, C. B. Exigência proteica de fêmeas ovinas mestiças. 2011. Dissertação (Mestrado em Ciência Animal) - Universidade Federal de Mato Grosso do Sul, Campo Grande.

RIBEIRO, C. V. D. M.; EASTRIDGE, M. L.; FIRKINS, J. L.; ST-PIERRE, N. R.; PALMQUIST, D. L. Kinetics of fatty acid biohydrogenation in vitro. Journal of Dairy Science, Champaign, v. 90, n. 3, p. 1405-1416. 2007.

SALDANHA, T.; SANTANA, D. M. N.; GASPAR, A. Nota prévia: lipídios totais, colesterol e composição de ácidos graxos da carne de capivara (Hydrochoerus hydrochaeris). Brasilian Journal of Food Technology, Campinas, v. 5, n. 1, p. 245-250, 2002

SALVATORI, G.; PANTALEO, L.; DI CESARE, C.; MAIORANO, G.; FILETTI, F.; ORIANI, G. Fatty acid composition and cholesterol content of muscles as related to genotype and vitamin $\mathrm{E}$ treatment in crossbred lambs. Meat Science, Amsterdam, v. 67, n. 1, p. 45-55, 2004.
SANTOS-SILVA, J.; BESSA, R. J. B.; SANTOS-SILVA, F. Effect of genotype, feeding system and slaughter weight on the quality of light lambs II. Fatty acid composition of meat. Livestock Production Science, Amsterdam, v. 77, n. 2, p. 187-194, 2002.

SCOLLAN, N. D.; HOCQUETTE, J. F.; NUERNBERG, K.; DANNENBERGER, D.; RICHARDSON, I.; MOLONEY, A. Innovations in beef production systems that enhance the nutritional and health value of beef lipids and their relationship with meat quality. Meat Science, Amsterdam, v. 74, n. 1, p. 17-33, 2006.

SINCLAIR, L. A. Nutritional manipulation of the fatty acid composition of sheep meat: a review. Journal of Agricultural Science, Cambridge, v. 145, n. 5, p. 419434, 2007.

SMIT, L. A.; BAYLIN, A.; CAMPOS, H. Conjugated linoleic acid in adipose tissue and risk of myocardial infarction. The American Journal of Clinical Nutrition, Houston, v. 92, n. 1, p. 34-40, 2010.

SOLOMON, M. B.; LYNCH, G. P.; PAROCZAY, E.; NORTON, S. Influence of rapeseed meal, whole rapeseed, and soybean meal on fatty acid composition and cholesterol content of muscle and adipose tissue from ram lambs. Journal of Animal Science, Champaign, v. 69, n. 10 , p. 4055-4061, 1991.

ULBRICHT, T. L. V.; SOUTHGATE, D. A. T. Coronary heart disease: seven dietary factors. The Lancet, London, v. 338 , n. 8773, p. 985-992, 1991.

VELASCO, S.; CAÑEQUE, V.; LAUZURICA, S.; PÉREZ, C.; HUIDOBRO, F. Effect of different feeds on meat quality and fatty acid composition of lambs fattened at pasture. Meat Science, Amsterdam, v. 66, n. 2, p. 457465, 2004.

WARREN, H. E.; SCOLLAN, N. D.; ENSER, M.; HUGHES, S. I.; RICHARDSON, R. I. WOOD, J. D. Effects of breed and a concentrate or grass silage diet on beef quality in cattle of 3 ages. I: animal performance, carcass quality and muscle fatty acid composition. Meat Science, Amsterdam, v. 78, n. 3, p. 256-269, 2008.

WOOD, J. D.; RICHARDSON, R. I.; NUTE, G. R.; FISHER, A. V.; CAMPO, M. M.; KASAPIDOU, E.; SHEARD, P. R.; ENSER, M. Effects of fatty acids on meat quality: a review. Meat Science, Amsterdam, v. 6, n. 1, p. 21-32, 2003.

ZENEBON, O.; PASCUET, N. S. (Coord.). Normas analíticas do Instituto Adolfo Lutz: métodos químicos e físicos para análise de alimentos. 4. ed. São Paulo: Instituto Adolfo Lutz, 2008. v. 1, 1020 p. 
